\title{
PENGARUH JENIS EDUKASI KESELAMATAN BERKENDARA TERHADAP PEMAHAMAN CALON PENGENDARA MOBIL DALAM MENGHADAPI KONFLIK LALU LINTAS
}

\author{
Chancard Basumerda ${ }^{1}$, Rini Dharmastiti ${ }^{2}$, Andi RahadiyanWijaya $^{3}$ \\ Jurusan Teknik Mesin dan Industri, Fakultas Teknik ${ }^{(1,2,3)}$, \\ Universitas Gadjah Mada, Jl. Grafika no 2 Yogyakarta. \\ Email :chancardb@yahoo.com
}

\begin{abstract}
Data of traffic accidents in Indonesia reveal high rate of traffic incidence. Lack of discipline, low driving skill, poor knowledge of traffic rules of drivers are at high risk. Education on traffic rules can be obtained easily from both printed and electronic media. Large amount of information on safety driving, however, has not significantly reduced traffic accident rate. Some types of education on safety driving available at present may not be effective for would-be drivers. The objective of the study was to identify the effective education in safety driving on the knowledge of perspective drivers when encountering traffic conflict. The study was conducted on 30 respondents aged 15-17 yeras, who were classified into 3 groups: 10 respondents used visual texts, 10 respondents used visual pictures, and 10 respondents used Audio Visual (an instructor). All respondents took pre-test and post-test. The result showed the type of education influenced would-be drivers' comprehension. Visual pictures and audio visual (an instructor) were the most effective types of education on safety driving for perspective drivers.
\end{abstract}

Key words: pre-test, post-test

\section{PENDAHULUAN}

Masalah transportasi jalan khususnya masalah keselamatan merupakan masalah setiap negara dan akan terus berkembang karena populasi penduduk dan kebutuhan melakukan perjalanan, terutama menggunakan kendaraan pribadi makin meningkat. Dalam empat tahun terakhir (2009-2012) terjadi peningkatan tingkat kecelakaan di jalan raya.

Faktor manusia mempunyai resiko yang sangat tinggi saat berkendara karena dipengaruhi oleh beberapa faktor diantaranya adalah tidak disiplin, tidak terampil dalam berkendara, lelah, dan tidak memahami beberapa peraturan atau ketentuan tata cara berlalu lintas. Tingginya angka korban kecelakaan baik yang meninggal dunia, luka berat, hingga luka ringan karena masih rendahnya tingkat disiplin berlalu lintas pengendara. 90\% kecelakaan disebabkan oleh faktor manusia sebagai pengendara, sisanya dikarenakan kondisi jalan, rambu lalu lintas, dan faktor kendaraan (Damayanti, 2012).
Di beberapa lembaga pelatihan mengemudi sudah memberikan edukasi mengenai tata cara berlalu lintas. Selain itu edukasi mengenai tata cara berlalu lintas juga mudah didapatkan melalui media cetak maupun elektronik.

Walaupun informasi mengenai berlalu lintas yang baik sudah banyak, hal tersebut tidak mengurangi angka kecelakaan di jalan raya. Beberapa edukasi yang sudah ada mungkin kurang efektif bagi calon pengendara. Maka dari itu Peneliti ingin mengetahui seberapa efektif edukasi keselamatan berkendara bagi para pengguna jalan khususnya calon pengendara mobil.

\section{TINJAUAN PUSTAKA}

Craen dkk (2013) menggunakan metode kuesioner adalah ingin mengetahui perbedaan pengemudi yang intensif pelatihannya dengan pengemudi yang bisa mengemudi karena kebiasaan.

Penggunaan metode kuesioner yang lain terdapat dalam penelitian yang dilakukan Zhao dkk (2012), yang disebut The Driver 
Behavior Questionnaire (DBQ), dimana suatu instrumen untuk memperoleh informasi pada tingkah laku mengemudi yang menyimpang. Instrumen tersebut berisi tentang beberapa aspek, yaitu kesalahan, kehilangan ingatan, dan pelanggaran. Selain itu Chen (2009) memiliki empat aspek, yaitu kepribadian, sikap aman, kelakuan resiko berkendara, dan demografis.

Penelitian yang menggunakan metode survey dilakukan oleh Newnam dkk (2012), dimana survey tersebut didistribusikan untuk memperoleh data berbasis dari pengemudi dan supervisor dengan waktu yang telah ditentukan. Metode tersebut juga dilakukan oleh Butters dkk (2012), dimana telah terlaksana oleh Transport Canada and Mothers Against Drunk Driving (MADD) Canada. Survey tersebut dilakukan dengan menelepon respondennya.

Tidak hanya dengan kuesioner dan survey, metode eksperimen pun telah dilakukan oleh peneliti sebelumnya, seperti yang dilakukan oleh Zhao dkk (2012), dengan menggunakan istilah feedback type, yaitu variabel antara subyek dengan tiga kondisi: no feedback, feedback without driver identity, dan feedback with driver identity.

Kecelakaan lalu lintas dipengaruhi oleh faktor manusia sebagai pengendara, fisik kendaraan, dan kondisi jalan, hal tersebut tercantum pada penelitian Pamungkas (2014), selain itu sangat penting untuk mengetahui perilaku pengendara kendaraan yang meliputi karakteristik, penginderaan, serta persepsi dan reaksinya dalam upaya mencegah terjadinya kecelakaan.

Penelitian Haryoko (2009) menyatakan bahwa media audio visual dapat meningkatkan efektivitas pembelajaran sekaligus memperkaya model pembelajaran dengan mengoptimalkan teknologi di dunia pendidikan pada umumnya dan domain pembelajaran pada khususnya. Novaliendry (2013) pada penelitiannya membuat sebuah desain aplikasi dalam rangka menemukan media pembelajaran yang efektif, dimana media pembelajaran tersebut menggunakan permainan edukasi berbasis multimedia interaktif. Dalam penelitian ini berkaitan dengan bentuk permukaan bumi, peta pengetahuan, dan negara. Dengan permainan edukasi tersebut meningkatkan kreativitas para responden.

Begitu pula dengan penelitian Purnawangsia (2013) dimana metode pembelajaran dengan permainan atau game (visual bergambar) merupakan salah satu metode yang mudah dipelajari, karena permainan itu identik dengan sesuatu yang menyenangkan sehingga responden akan merasa nyaman. Tetapi tidak hanya kesenangan saja, metode pembelajaran tersebut juga dapat memberikan ilmu pengetahuan. Hal ini juga dilakukan oleh Zhao dkk (2012) menggunakan alat simulator sebagai media pembelajarannya, dimana hasilnya meningkatkan potensi keselamatan berkendara.

Berdasarkan tinjauan pustaka tersebut penelitian ini mencoba menggabungkan tiga jenis edukasi, sebagai bahan pertimbangan yang diteliti dalam penelitian ini. Namun, untuk membedakan dengan penelitian yang lain dan berdasarkan pada latar belakang sebelumnya, penelitian ini akan membahas mengenai jenis edukasi yang efektif untuk keselamatan berkendara terhadap pemahaman calon pengendara mobil dalam menghadapi konflik lalu lintas.

\section{METODE PENELITIAN}

Subyek penelitian adalah responden dengan usia 15-17 tahun dan belum memiliki Surat Ijin Mengemudi kategori A (SIM A). Responden dalam kondisi sehat, tidak buta warna, dan tidak mengalami gangguan pendengaran. Penelitian yang dilakukan Zhao dkk (2012), jumlah sampel yang digunakan yaitu 30 sampel sehingga responden pada penelitian ini adalah 30 calon pengendara yang belum memiliki SIM A, yang dibagi menjadi 3 kelompok, yaitu 10 responden dengan perlakuan visual (teks), 10 responden dengan perlakuan visual (gambar), dan 10 responden dengan perlakuan audio visual (instruktur). 
Penetapan tujuan dilakukan untuk menetapkan apa yang dilakukan dalam penelitian. Penetapan Tujuan dilakukan untuk mengetahui output dalam penelitian nanti. Penelitian ini menggunakan modul yang digunakan untuk eksperimen. Modul berisi tentang peraturan perundang undangan berkendara lalu lintas yang selanjutnya ditampilkan berupa gambar. Selain itu ditambahkan contoh - contoh kasus yang lainnya.

Pada eksperimen diberlakukan dua kali tes (pre test dan post test), dimana tes tersebut diambil di LPL Akreditas. Setelah mendapatkan pre test, responden akan dibagi menjadi tiga kategori, yaitu responden yang menggunakan modul visual (teks), responden yang menggunakan modul visual (gambar), dan responden menggunakan audio visual (instruktur). Pemilihan responden akan dilakukakan secara random. Setelah itu responden melakukan post test dengan tes yang sama dengan sebelumnya.

Pengolahan data dilakukan setelah mendapat data yang ada di lapangan dan telah dilakukan. Pengolahan data dilakukan menggunakan microsoft excel. Kemudian digunakan juga software SPSS untuk mencari distribusi yang ada pada data. Software SPSS juga digunakan untuk melakukan berbagai uji statistik yang dilakukan pada data yang sudah didapat.

Uji normalitas data dimaksudkan untuk memperlihatkan bahwa data sampel yang diperoleh berasal dari populasi yang berdistribusi normal. Uji kenormalan data juga digunakan dalam penentuan metode pengujian data selanjutnya. Jika data terdistribusi normal maka digunakan pengujian statistik parametrik seperti ANOVA (Analysis of Variance), sebaliknya jika data tidak terdistribusi normal, maka langkah berikutnya adalah dengan melakukan pengujian statistik nonparametrik seperti uji wilcoxo.

Merupakan salah satu teknik analisis untuk membedakan rerata lebih dari dua kelompok data dengan cara membandingkan variansinya. Penggunaan metode two way ANOVA biasanya jika terdapat 2 variabel independen dan satu dependen variabel. Analisis varian termasuk dalam kategori statistik parametrik. Sebagai alat statistika parametrik, maka untuk dapat menggunakan rumus ANOVA harus terlebih dahulu perlu dilakukan uji asumsi meliputi normalitas, heterokedastisitas dan random sampling.

\section{HASIL DAN PEMBAHASAN}

Berdasarkan hasil perhitungan dengan menggunakan uji statistik, didapatkan hasil penelitian sebagai berikut:

1. Dalam kondisi Pre Test bahwa tidak terdapat perbedaan yang signifikan antara jenis edukasi dengan pemahaman.

2. Dalam kondisi Post Test terdapat perbedaan yang signifikan antara jenis edukasi dengan pemahaman.

Perbandingan rata - rata kondisi Pre Test dan Post Test ditampilkan pada Gambar. 1.

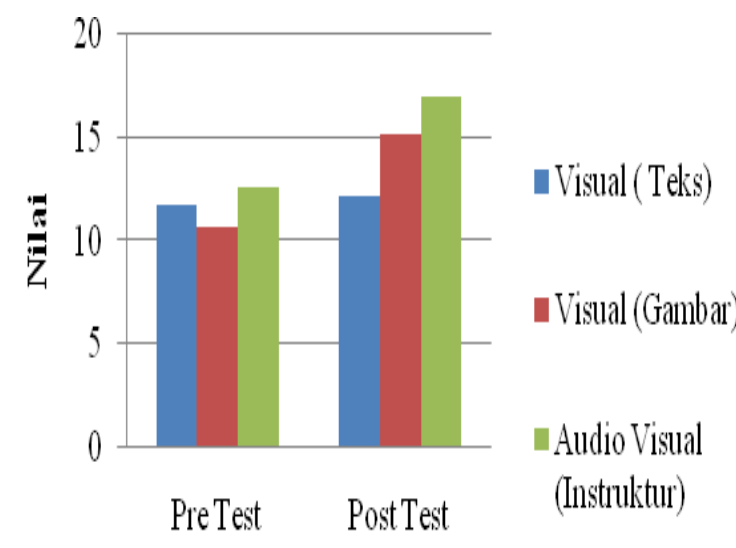

Kondisi

Gambar. 1 Rata - Rata Kondisi

Pre Test dan Post Test.

Rata - rata kondisi Pre Test adalah Visual-Teks $(11,8)$, Visual-Gambar $(10,7)$, dan Audio Visual-Instruktur (12,6), untuk kondisi Post Test adalah Visual-Teks $(12,2)$, Visual-Gambar $(15,2)$, dan Audio VisualInstruktur (17). Dengan melihat nilai ratarata di atas, terlihat perbedaan kondisi pre test dan post test. Kondisi pre test ketiga jenis edukasi memiliki rata - rata yang tidak jauh berbeda, namun kondisi post test menunjukkan pengaruh tiap jenis 
edukasinya. Visual (Gambar) dan Audio Visual (Instruktur) memberikan pengaruh sehingga pemahaman menjadi meningkat.

Dari penelitian ini didapatkan hasil bahwa Visual (Gambar) dan Audio Visual (Instruktur) memberikan efek terhadap pemahaman calon pengendara mobil dalam menghadapi konflik lalu lintas. Menurut Crundall et al. (2010), metode instruktur memberikan efek yang signifikan bagi perilaku pengemudi.

Penelitian yang dilakukan Kawuryan et al. (2012), bahwa stimulasi visual memberikan perbedaan yang signifikan pada kemampuan membaca anak, dimana anak yang diteliti adalah anak disleksia. Disleksia adalah sebuah kondisi ke tidak mampuan belajar pada seseorang yang disebabkan oleh kesulitan pada orang tersebut dalam melakukan aktivitas membaca dan menulis.

Stimulasi visual adalah stimulasi yang dilakukan dengan melihat suatu obyek, sehingga obyek tersebut tersimpan dalam ingatan. Media yang berbasis visual memberikan peranan penting dalam proses belajar karena dengan media visual dapat memperlancar pemahaman dan memperkuat ingatan. Hal tersebut berkaitan dengan memori jangka panjang, dimana memori jangka panjang adalah penyimpanan memori secara permanen, yang mengandung simbol terstruktur, dan memori juga mempunyai kapasitas yang tidak memadai.

Tidak hanya visual, namun media audio visual juga dapat meningkatkan pembelajaran yang efektif, penelitian yang dilakukan oleh Haryoko (2009), dengan menggunakan media audio visual, hasil belajar mahasiswa memiliki skor jauh lebih tinggi dibandingkan pengajaran yang menggunakan media konvensional atau tradisional.

\section{KESIMPULAN}

Berdasarkan penelitian yang telah dilakukan, didapatkan hasil bahwa jenis edukasi yang efektif untuk keselamatan berkendara terhadap pemahaman calon pengendara mobil dalam menghadapi konflik lalu lintas adalah Visual (Gambar) dan Audio Visual (Instruktur).

\section{DAFTAR PUSTAKA}

Butters, J., Mann, R., E., Wickens, C., M., Boase $\mathrm{P}$, Gender Differences and Demographic Influences in Perceived Concern for Driver Safety and Support for Impaired Driving Countermeasures, Journal of Safety Research, 405-411, 2012.

Chen, C., F, Personality, Safety Attitudes and Risky Driving BehaviorsEvidence From Young Taiwanese Motorcyclists, 2009, Accident Analysis and Prevention, 963-968, 2009.

Craen, S., Vlakveld W., P, Young Drivers who Obtained Their Licence After an Intensive Driving Course Report More Incidents Than Drivers With a Traditional Driver Education, Accident Analysis and Prevention 45, 354-365, 2013.

Crundall, D., Andrews B., Loon E., Chapman $\mathrm{P}$, Commentary Training Improves Responsiveness to Hazards in a Driving Simulator, Accident Analysis and Prevention 42, 2117-2124, 2010.

Damayanti, A.,T., Analisis Hubungan Pemahaman Resiko Kecelakaan Dengan Penggunaan Perlengkapan Keselamatan dan Perilaku Berkendara Serta Usulan Peningkatan Keselamatan Pengguna Sepeda Motor, Tesis Program Studi Magister Sistem dan Teknik Transportasi Universitas Gadjah Mada,Yogyakarta, 2012. 
Haryoko, S, Efektivitas Pemanfaatan Media Audio Visual Sebagai Alternatif Optimalisasi Model Pembelajaran, Jurnal Edukasi, vol 5 no 1, 2009.

Kawuryan, F., Raharjo T, Pengaruh Stimulasi Visual untuk Meningkatkan Kemampuan Membaca pada Anak Disleksia, Jurnal Psikologi Pitutur, vol 1 no 1, 2012.

Newnam, S., Lewis, I., Watson B., Occupational Driver Safety: Conceptualising a LeadershipBased Intervention to Improve Safe Driving Performance, Accident Analysis and Prevention 45, 29-38, 2012.

Novaliendry, D, Aplikasi Game Geografi Berbasis Multimedia Interaktif, Jurnal Teknologi Informasi dan Pendidikan, vol 6 no 2, 2013.

Pamungkas, N., S, Mengenal Perilaku Pengendara Kendaraan Dalam Upaya Mencegah Terjadinya Kecelakaan Di Jalan Raya, Teknis, vol 9 no1, 2014.

Purnawangsia, S., Amirullah, D., Nasir, M. Game Edukasi Teka Teki Silang Digital Berbasis Teknologi Informasi, Seminar Nasional Industri Teknologi, vol 2 no 1 , 2013.

Zhao, G., Wu, C., The Effects of Driver Identity on Driving Safety in a Retrospective Feedback System, Accident Analysis and Prevention 45, 354-365, 2012.

Zhao, N., Mehler, B., Reimer, B., D`Ambrosio, L., A., Mehler, A., Coughlin, J., F, An Investigation of The Relationship Between The Driving Behavior Questionnaire and Objective Measures of Highway Driving Behavior, Transportation Research Part F 15, 676-685, 2012. 